\title{
The effects of adaptation to climate change on income of households in rural Ethiopia
}

\author{
Melaku Berhe ${ }^{1,2,3,4,5^{*}}$, Dana Hoag ${ }^{1,2,3,4,5}$, Girmay Tesfay $1,2,3,4,5$, Tewodros Tadesse ${ }^{1,2,3,4,5}$, Shunji Oniki 1,2,3,4,5, \\ Masaru Kagatsume ${ }^{1,2,3,4,5}$ and Catherine M. H. Keske $e^{1,2,3,4,5}$
}

\begin{abstract}
Climate change is one of the most serious impediments to agricultural prosperity in Ethiopia, especially where livestock is concerned. In particular, rural farming communities in the drylands of the Afar region are severely exposed to the impacts of climate change, with stark reminders from repeating droughts followed by crop failure and livestock decimation. Locals have a long history of applying adaptation measures to maintain their sustenance. However, a growing literature challenges whether these traditional methods can continue to sustain local livelihoods. This study identifies how pastoral, semi-pastoral, agro-pastoral and mixed-farming communities in Afar perceive and adapt to climate change and whether these practices have brought about any improvement in farm income. A panel data set of five years was gathered using structured questionnaires from a sample of 313 households. Household heads pointed out indicators to identify climate-related stress such as erratic rainfall, drought, temperature change, drying of water sources, prevalence of diseases and lack of human and livestock feed. A fixed effects quantitative model on the panel data was estimated to verify the effect of adaptation strategies on income of household heads. We found that the main adaptation strategies that significantly influenced household income levels were forage production (hay and straw), access to water sources, livestock diversification and migration. The implication is that people severely affected by climate change and living in a situation demanding urgent solutions can actively apply various adaptation strategies if the strategies are linked to the creation of sustainable income benefits. Thus, integrated approaches comprising adaptation methods and expected benefits are an important way to induce farming communities to address challenges related to climatic change.
\end{abstract}

Keywords: Adaptation, Cattle, Climate change, Income, Pastoral

\section{Introduction}

The dire effects of climate change have plagued the livelihoods of rural communities in East Africa for generations. Land degradation attributed to human, drought and climate factors is increasingly threatening the four main agricultural communities: pastorals, semi-pastorals, agropastorals and mixed-farming, especially in the drylands regions of East Africa (Adger et al. 2005; Sandford 2006; Stringer et al. 2009). Adaptation strategies, such as livestock mobility, diversification, feed purchases and animal restocking, have increasingly become unable to support

\footnotetext{
* Correspondence: melakuberhe@gmail.com

'Department of Agricultural and Resource Economics, College of Dryland

Agriculture and Natural Resources, Mekelle University, P.O.Box 231, Mekelle, Ethiopia

${ }^{2}$ Department of Agricultural and Resource Economics, Colorado State University, Fort Collins, CO 80523-1172, USA

Full list of author information is available at the end of the article
}

their livelihoods (Wassie and Fekadu 2014; Kima et al. 2015). Moreover, dependence on livestock rearing is increasingly constrained by population growth, which results in the occupation of grazing areas by human settlements (emergence of new villages) and urbanization (Tsegaye et al. 2013). Although population growth and the gradual emergence of peri-urban centres are potential sources of market opportunities for livestock producers (Markakis 2004), the future livelihoods of rural communities given the contemporary climatic change have remained among one of the biggest challenges in the region (Sandford 2006).

There are two contrary debates focused on whether pastoral lifestyles could serve as an adaptation strategy to climate change in the drylands regions of East Africa. The first contends with deep pessimism about the pastoral mode of life, viewing pastoralism an old living 
system by which pastoralists could not meet their livelihood requirements (Sandford 2006). Pastoralists live in drylands areas characterized by repeating droughts, land degradation, lack of marketing, governance and access to technology (Bradburd 1982; Hogg 1992). And even these limited resource regions are being further stressed by human population growth. In the Greater Horn of Africa, pressure on the ecological base of rangelands threatened carrying capacity to support huge livestock herds that eventually left pastoralists in crisis (Sandford 2006). According to Sandford (2006), introducing improved livestock management with permanent settlement should be prioritized and this can be credible if it is integrated with irrigation and mixed livestock-cereal production and with forage enhancement schemes. His argument emphasizes that settling pastoral communities into permanent locations leads to the provision of basic infrastructure including schools, health services, road accesses, and veterinary services.

The second strand of literature strongly advocates the importance of the pastoral living style to maintain livelihoods through traditional systems (Moritz et al. 2009; Nassef et al. 2009). Pastoralists have a long history of involvement in various forms of adaptation methods based on their own indigenous knowledge (African Technology Policy Studies Network 2013). Research findings (see OXFAM 2008; Moritz et al. 2009) demonstrate that the pastoral system is an easy way to adapt to climatic effects, owing to its suitability to arid and semi-arid environments through strategies of establishing strong social capital, economic cooperation among community members and clan lineage networks, herd diversification and restocking methods. In such a context, pastoral life allows the community to keep their cultural systems and knowledge while responding to the negative effects of climate change. Instead of changing the prolonged indigenous mode of living into the proposed new style of life, more attention is needed to enhance mobility strategies in a way that supports adaptive capacity by introducing modern extension services and veterinary facilities.

Clearly, there is a divergence of opinions about the sustainability of the pastoral way of life and its corresponding contribution towards climatic adaptation in the drylands regions of Africa. This is complicated by the multifaceted nature of adaptation possibilities that are heavily dependent on a variety of factors such as market accessibility and institutions (Smit et al. 2000), resource availability (Sandford 2006), demand pressure of human and livestock populations for limited land size (Tsegaye et al. 2013) and availability of livelihood options apart from livestock earnings (Adger et al. 2005; Berhanu et al. 2007; Galvin 2009). Considering the existence of pastoral, semi-pastoral, agro-pastoral and mixed-farming communities in the region, it is difficult to clearly point out exactly how these two debates fit into policy actions without having sizeable evidence. This requires a thorough investigation about how multiple adaptation strategies influence the adaptive capacity of these communities.

This study examines what and how major factors influence the adaptive capacity of rural communities in the Afar region of Ethiopia, including to what extent adaptation methods are applied and which adaptation methods contribute to household income. This is important because rural communities in the Afar region account for about $29 \%$ of the country's total population and $16 \%$ per annum of total GDP (CSA (Central Statistical Authority) 2008). While most of these communities meet their subsistence living via engaging in animal production, the natural resource base in the region is highly subject to overgrazing and deforestation, with an increasing number of human and livestock populations (Tsegaye et al. 2010), which has accelerated (Galvin 2009). Such challenges combined with unpredictable rainfall and changing temperature (Campbell et al. 2005; Sandford 2006) leave villagers vulnerable to economic disasters. Therefore, understanding how locally practised adaptation strategies uphold the livelihoods of rural communities is paramount to improve their lives. It is unclear which adaptation strategies lift livelihoods across the community groups.

The large body of previous literature is focused on climate modelling techniques for identifying future threats of climate change and outlining adaptation approaches. Options for adaptation include diversifying income, building formal and informal institutions, adjustments in livestock holdings and species, labour mobility and engagement in small irrigation schemes (Adger et al. 2005; Berhanu et al. 2007; Seo and Mendelsohn 2008; Moritz et al. 2009; Crane et al. 2011; Tsegaye et al. 2013). However, little empirical knowledge is available to help understand the effects of alternative adaptation strategies on household incomes. Hence, this study has three objectives: (1) to determine how pastoral, semi-pastoral, agro-pastoral and mixed-farming communities perceive the effects of climatic change; (2) to examine how they adapt to these changes and (3) to estimate how that affects their income. Results are based on a survey of over 300 pastoral, semi-pastoral, agro-pastoral and mixed-farming communities.

\section{Methods}

The use of multiple adaptation strategies in response to climatic change by a farm household is often a decision made based on observable and unobservable household, farm and community-specific attributes. These attributes play pivotal roles when farm households make decisions under different risk scenarios. In effect, households' 
adaptation decisions are jointly determined in response to climatic fluctuations, and hence the livelihood activities that form the basis for earning income. The significance of inter-dependent decision-making in adaptation and subsequent income is even more pronounced among pastoral, semi-pastoral, agro-pastoral and mixed-farming communities living in drylands regions that are at greater chance of experiencing loss of livestock (Tsegaye et al. 2013). In responding to livestock loss due to climate change, such livestockdependent households widely apply local-based adaptation measures that are applicable and easily affordable (Di Falco et al. 2012).

Assuming that farm households make rational decisions, their involvement in the implementation of various adaptation measures is linked to maximizing future benefits. These expected benefits induce households to continue using various adaptation strategies that provide them with a maximum level of unobserved utility (Barberies 2013). Across time, households can enjoy different levels of unobserved utility emanating from variations in expected benefits in different periods. In effect, a household's utility can change from time to time in response to the changing preferences, which in turn reflect the changes in both observable and unobservable characteristics. In this setup, household $i$ 's latent utility derived from a specific adaptation strategy $j$ at a given point in time $t$ can be denoted as

$$
U_{i j, t}=U\left(\mathbf{x}_{i j, t}, \mathbf{h}_{i j, t}, \mathbf{a}_{i j, t} ; \varepsilon_{i j, t}\right)
$$

where $U$ is the unobserved (latent) utility attributed to a particular adaptation strategy for household, $\mathbf{x}$ is the vector of observable characteristics that also vary in time (time varying characteristics), $\mathbf{h}$ is the set of time and choice invariant characteristics of the farm household, a is the vector of unobservable factors (both time varying and time invariant) that represent unobservable heterogeneity among farm households involved in adaptation decision-making and finally $\varepsilon$ represents time varying and time invariant unobserved and random term.

Effectively, a household's utility is reflected in terms of their preferences for carrying out compatible adaptation actions. As a result, their preferences rely on the extent of the income benefits they expect to gain from their involvement in several adaptation measures. In this regard of modelling the behaviour of rural households acting as a producer, a consumer or both, it is assumed that utility evolving from households' involvement in a random way is explicitly expressed in terms of improved income levels. Considering a given household has persistently applied several adaptation measures over a series of years, the utility maximization equation can be presented as

$$
\underset{\mathbf{x}, \mathbf{h}, \mathbf{a}}{\operatorname{Max}}=\mathrm{U}\left(\mathbf{x}_{i j, t}, \mathbf{h}_{i j, t}, \mathbf{a}_{i j, t}\right)
$$

As a result, maximized utility levels are driven by income improvements. Income of households is in turn a function of various adaptation measures, availability of resources and other supports readily utilized by households. Overall, farming communities are free to apply individual or village-based adaptation measures while seeking to meet their income levels. The income earned by farm households can be from multiple sources such as cropping, livestock, agricultural wages and nonagricultural wages. For such analysis, several adaptation variables are taken into account including livestock mobility, use of small scale irrigation schemes, fodder stocking (feed), animal restocking and destocking, pasturing and cropping.

Based on this framework, this study distinguishes the effect of adaptation methods on household income levels in situations where pastoral, semi-pastoral, agro-pastoral and mixed-farming communities confront multiple effects of climate change and whose income level is thought to be highly fluctuating. It is common that income varies among households that adopt different livelihood strategies. This income over a period changes in response to different factors. Crucially, the factors may or may not also change overtime. Hence, modelling farm household income variation in response to different observable and unobservable factors needs to take this into account. In modelling farm household income (to explain income as a function of variables), therefore, there is an important issue that needs to be addressed - omitted variable bias. Farm households' ability (capability) to make use of adaptation strategies for managing or maintaining mainly farm production and thereby augment income could be influenced by many unobservable factors. In other words, farm households could exhibit heterogeneity, due to unobservable factors that are difficult to capture or collect data using surveys. In effect, using data collected at one point in time (cross-sectional data) for estimating the effect of adaptation strategies on income could lead to biased results. This is because decision-making behaviour during adaptation could be correlated with the unobserved household heterogeneities. Therefore, analysis based on panel data helps address this problem associated with omitted variable bias of heterogeneity. This is where the fixed effects model becomes helpful as it addresses the effects of variables that never vary over the panel years (see Wooldridge 2002).

We can reformat the empirical modelling using the fixed effects regression as follows: 


$$
y_{i t}=\boldsymbol{\beta}^{\prime} \mathbf{x}_{i k, t}+a_{i}+u_{i t}
$$

where $y_{i t}$ represents household $i$ 's income measured in Ethiopian Birr, $\mathbf{x}_{i t}\left(x_{i 1, t}, x_{i 2, t}, \ldots, x_{i k, t}\right)$ represents the vector of explanatory variables, $t$ refers the time period $(t=1,2, . .5), a_{i}$ represents the fixed effects (a vector of unobserved effects), $u_{i t}$ denotes the error term across years and $\boldsymbol{\beta}^{\prime}=\left(\beta_{1}, \beta_{2}, \ldots, \beta_{k}\right)$ represents the corresponding vector of estimated coefficients. In the setup of Eq. (3), any effect that may originate due to the influence of fixed variables is controlled by the fixed effects model (Verbeek 2004). This model removes the influence of those time-invariant characteristics from the independent variables while extracting the net effect of each independent variable, which varies over the panel years (Baltagi 2005). Another important advantage of using the fixed effects model is that it takes into account those unique time-invariant individual characteristics that should not be correlated with other individual characteristics (Wooldridge 2002).

If the error terms are systematically correlated, then tests are warranted to see whether it requires random effects or fixed effects, which necessitates applying the Hausman test (Baltagi 2005). This is because the correlation between the fixed effects $a_{i}$ and the explanatory variables $\mathbf{x}_{i t}$ will cause biases in the estimated coefficients. Thus, we need to eliminate the effects of fixed variables represented by $a_{i}$ from the estimation. First, we computed the sample average variables for each household. That is, for the $i$ th household, we divided Eq. (3) by time $t$ to obtain Eq. (4) in the following form:

$$
\bar{y}_{i}=\boldsymbol{\beta}^{\prime} \overline{\mathbf{x}}_{i k}+a_{i}+\bar{u}_{i}
$$

Since $a_{i}$ is constant over time, the $a_{i}$ term in Eq. (4) does not have a bar over it. Next, we subtract (4) from (3) to get the following equation called the within fixed effects transformation (Baltagi 2005).

$$
\left(y_{i t}-\bar{y}_{i}\right)=\boldsymbol{\beta}^{\prime}\left(\mathbf{x}_{i k, t}-\overline{\mathbf{x}}_{i k}\right)+\left(u_{i t}-\bar{u}_{i}\right)
$$

The net effect captured by Eq. (5) is free from effects of time-invariant variables that we cannot measure in farming practices across years. Thus, this estimation allows us to observe the pure effect of applying various adaptation methods on income levels during the five consecutive years.

Considering the nature of rural income, adaptation methods are dynamically interrelated to each other and this further requires verifying the effect of lagged income (income of previous year) on current income. Hence, a limitation of fixed effects model that may arise due to the inclusion of lagged variable (lagged income) was checked using dynamic panel model as shown in Eq. (6).

$$
y_{i t}=\theta y_{i, t-1}+\boldsymbol{\beta}^{\prime} \mathbf{x}_{i k, t}+\varepsilon_{i t}
$$

where $\varepsilon_{i t}=u_{i t}+\mu_{i}$. In such dynamic panel setup, the dependent variable, i. e. the income of pastoral, semipastoral, agro-pastoral and mixed-farming communities, depends on observed explanatory variables signified by $\mathbf{x}_{i t}$, latent effects represented by $\varepsilon_{i t}$ and the lagged dependent variable $\left(y_{i, t-1}\right)$ whose coefficient is designated by $\theta$. The error term, $\varepsilon_{i t}$, constitutes time effect, which arises from heterogeneous behaviour of individuals $\left(u_{i t}\right)$ and time invariant variables $\left(\mu_{i}\right)$ (Nickell 1981; Kiviet 1995; Baltagi 2005). In situations where time effect was considerable, the use of dynamic panel modelling was required because the inclusion of lagged dependent variable as a regressor might result in an autocorrelation problem and lead to biased estimates of fixed effects model. In this case, we tested whether the dependent variable $\left(y_{i t}\right)$ becomes to be a function of $\mu_{i}$. As indicated in the 'Results and discussion' section, we conducted A series of tests to check if the lagged dependent variable $\left(y_{i, t-1}\right)$ was serially correlated to the error term $\left(\mu_{i}\right)$, which was also helpful to verify the need for the use of dynamic fixed effects model to this study.

\section{Study areas and data \\ Description of study area}

This study was conducted in the district of Abaala in the Afar regional state of northeastern Ethiopia. The Afar region is situated in the great East African Rift Valley, which is bordered by the Oromia regional state on the southwest and south, Amhara regional state on the northwest, Tigray regional state on the northeast and Somali regional state on the southeast. Specifically, the Aba'ala district lies between the highland escarpments of the Tigray region and the world's lowest area called the Dankil Depression. Aba'ala records highly fluctuating rainfall with an estimated variation coefficient of 33\%, relatively varying from year to year (Meze-Hausken 2004). Its annual average rainfall ranges between 150 and $500 \mathrm{~mm}$ (Tsegaye et al. 2010), and it frequently receives very erratic rainfall during the 'Karma' season, which constitutes the rainy season between mid-June and mid-September. While the district has a mean temperature varying from 20 to $48^{\circ} \mathrm{C}$, its altitude ranges from $100 \mathrm{~m}$ below sea level in Berahle to 1,500 m above sea level in Wuhdet (the town centre of Aba'ala district). The district is populated with nearly 37,943 inhabitants living over an area of about $1,188.72 \mathrm{~km}^{2}$ (CSA (Central Statistical Authority) 2008).

In the face of climatic change, livelihood strategies pursued by the communities in the Aba'ala district are grouped into four categories, namely pastoral, semipastoral, agro-pastoral and mixed-farming (Tsegaye et al. 2013). Each category has its own peculiarity in responding 
to the risks of climate change. For a long period of time, pastoralists were the early pioneers of Aba'ala district. Tracing back to the historical connections established between the pastoralists and migrants from the highlands of neighbouring Tigray, both communities started living and working together since the middle of the twentieth century (Kloos 1982). As the result, migrants from the Tigray region continued practising crop farming and animal husbandry in Aba'ala. It was since that time the district became known for its rain-fed agricultural suitable for growing maize, sorghum and some cereals like tef and barley (Tsegaye et al. 2010). This has enhanced strong linkages between the indigenous pastoralists and the highland communities in terms of their economic interests and marriages. Realizing the negative effects of climatic change on their livelihood bases, the Afar pastoralists gradually began supplementing their food gaps through farming crops along with livestock herding.

\section{Data}

The Aba'ala district was chosen for two reasons. First, the district is characterized by its dryness and the common phenomenon of drought occurrences for about five decades. Due to its geographical remoteness from the Awash River and other perennial rivers, Aba'ala is one of the districts in northern Afar currently suffering from lack of water and access to grazing areas during drought periods. Second, the existence of indigenous experiences of adaptation methods practised by pastoral, semipastoral, agro-pastoral and mixed-farming communities in the district motivated this research, specifically to formulate a detailed analysis on relationships between various adaptation strategies and household income. The livelihood bases of the Afar communities depend on their involvement in livestock rearing, cropping and mixed crop-livestock farming systems. Household adaptation strategies vary across communities in Aba'ala district (Tsegaye et al. 2013). Pastoral communities are those whose means of living entirely depends on raising livestock. These communities are widely known for managing their livestock through a nomadic strategy. They pursue livestock mobility in search of natural pasture and water sources. Semi-pastoral community members are those who were originally pure pastoralists but started to evolve into cropping over the last three decades. Although these communities are land owners, their involvement in cropping is only through renting or sharecropping to other farmers. Their livelihood dominantly depends on livestock rearing with a sedentary lifestyle in permanent houses. Their adaptation strategies to climate change and drought include livestock mobility, sharecropping, trading and participating in some other off-farm activities such as wages and salaries. The agro-pastoral community members mainly raise cattle, have their own land and directly produce cereals. They cope with adverse events of climate change by collecting animal feed (hay and straw, purchase formula feed and use artificial insemination). The mixed crop-livestock farming community members have their own land and rent-in or share-in cultivable land from others (mainly from semi-pastorals). The main source for their living is crop faming. They keep raising a small number of cattle for draught power and small ruminant animals to supplement their produce from cropping.

Data from the four communities were collected in two stages of primary surveys. First, a reconnaissance appraisal was conducted to have a broader understanding on adaptive behaviours of farmers that dwell in the study area. During the exploratory survey, a series of discussions were held with various stakeholders including clan leaders, farmers, pastoralists, agro-pastoralists, extension workers and agricultural experts. Pertinent information obtained from the first stage was used to refine the study objectives, sampling methods and the survey instrument. In the second stage, we stratified the community into mixed-farming, agro-pastoral, semi-pastoral and pastoral, whereby sample households were selected from each stratum randomly. Based on the four community classifications, sampling across 11 Kebeles (villages) in the Aba'ala districts was made. Out of the 11 Kebeles, five were pastorals, three were semi-pastorals, one was agro-pastoral; the remaining two are mixed-farming communities. To ensure appropriate representation of each stratum, a two-stage stratification sampling method was applied to minimize heterogeneities among groups (strata).

In total, there were about 2,236 households across the four groups. Proportionately, the number of households in each stratum (group) constituted 763 pastoral, 287 semi-pastoral, 508 agro-pastoral and 678 mixed-farming communities. In the end, 325 representative sample households were randomly selected from the four groups, out of which, 110 (33.3\%) were pastoral, 43 (12.8\%) semi-pastoral, 74 (22.7\%) agro-pastoral and 98 (31.2\%) mixed-farming communities. Among those 325 household heads randomly selected for sampling, we were unable to collect data from 12 households due to change in their address during the five consecutive years. Hence, a balanced panel data of 313 sample households was gathered in 2011, 2012, 2013, 2014 and 2015. To preclude seasonal variations, data collection was conducted every November. Four enumerators who have good knowledge regarding the study area were hired and trained for the survey. After developing and completing preparation of the structured questionnaire, a pre-test survey was conducted on 12 households, the feedbacks of which were incorporated in the full survey.

Qualitative data were also gathered to supplement data types that cannot be obtained via quantitative methods. 
This would validate the quantitative results to come up with storylines of information about local practices of adaptation to climate change for improving their livelihood sources. Before setting out on fieldwork for data collection, clan leaders, religious leaders, agricultural experts, village administrators and elders were selected to hold group discussions. The important criterion for the inclusion of such discussions in this context was based on their pertinence for substantiating the findings. During the discussion, ethnographical methods were used to explore the contribution of Afar communities and highland settlers in building livelihood assets.

\section{Results and discussion}

\section{Statistics and variable descriptions}

As shown in Table 1, the mean age of households was 48.9 years. A given household constituted an average family size of six members whose age ranged between 15 and 64 years. According to International Labor Office (ILO 2011), this age category is termed as the active economic labour force population. This shows that the availability of the active labour force in rural areas is an opportunity to apply locally based adaptation strategies. For instance, a physically capable labour force can easily accomplish various environmental conservation actions, which would enable the locals to cope with risks related to climatic change. The implication is that local development plans that incorporate participation of an active labour force across rural villages may enhance sustainable income options and minimizing climate-related risks. The study findings also indicated that the average size of families whose age was below 15 and greater than 64 years were 3 and 0.09 , respectively. The ILO (2011) named these age categories as a dependent labour force.

In terms of gender distribution, $84 \%$ of the household heads were males and the remaining $16 \%$ were females. Based on ideas obtained from key informants and group discussants, females in the Afar region were generally burdened with indoor family management tasks, which deterred them from accessing various income-generating activities such as possible benefits from livestock rearing and off-farm activities. The result is consistent with other studies conducted by Chala et al. (2012) and FAO (2012). Females in Ethiopia have cultural hindrances that obstruct their involvement in various developmental activities outside their home. Women are highly engaged in family management and indoor house duties such as cooking, washing and taking care of their children. Because of these extra burdens, it is hard for them to access formal education and work outside homes seeking to supplement their financial situations. Among the household heads, $66.9 \%$ did not get any chance to get a formal education, $19.6 \%$ could write and read, $13.5 \%$
Table 1 Summary statistics and variable descriptions $(n=313)$

\begin{tabular}{|c|c|c|}
\hline Variables and specification & Mean & Standard deviation \\
\hline Age of household head (years) & 48.9 & 10.7 \\
\hline $\begin{array}{l}\text { Sex of household head } \\
(1=\text { Male, } 0=\text { Female })\end{array}$ & 0.84 & 0.36 \\
\hline $\begin{array}{l}\text { No. of family members aged below } \\
15 \text { years (number) }\end{array}$ & 3.0 & 1.01 \\
\hline $\begin{array}{l}\text { No. of family members aged } 15 \text { to } \\
64 \text { years (number) }\end{array}$ & 6.0 & 2.13 \\
\hline $\begin{array}{l}\text { Family members aged above } 64 \text { years } \\
\text { (number) }\end{array}$ & 0.09 & 0.30 \\
\hline $\begin{array}{l}\text { Education of household head } \\
(1=\text { Illiterate, } 2=\text { Read and write, } \\
3=\text { Primary, } 4=\text { Secondary, } 5=\text { Tertiary })\end{array}$ & 66.9 & 0.72 \\
\hline $\begin{array}{l}\text { Working experience in livestock } \\
\text { farming (years) }\end{array}$ & 25.17 & 11.42 \\
\hline $\begin{array}{l}\text { Repeating move for more than one } \\
\text { month }(1=\text { Yes, } 0=\text { Otherwise })\end{array}$ & 0.06 & 0.24 \\
\hline $\begin{array}{l}\text { Access to water sources } \\
(1=\text { Yes, } 0=\text { Otherwise })\end{array}$ & 0.85 & 0.34 \\
\hline Stocking fodder ( $1=$ Yes, $0=$ Otherwise $)$ & 0.22 & 0.41 \\
\hline $\begin{array}{l}\text { Access to extension services } \\
(1=\text { Yes, } 0=\text { Otherwise })\end{array}$ & 0.02 & 0.14 \\
\hline Cropping (1 = Yes, 0 = Otherwise) & 0.65 & 0.47 \\
\hline $\begin{array}{l}\text { Size of cattle holding } \\
\text { (total livestock unit) }\end{array}$ & 6.77 & 2.61 \\
\hline Size of goat (total livestock unit) & 15.5 & 22.9 \\
\hline Size of sheep (total livestock unit) & 0.03 & 0.31 \\
\hline Size of camel (total livestock unit) & 0.30 & 1.15 \\
\hline Diversification ( 1 = Yes, 0 = Otherwise) & 0.15 & 0.36 \\
\hline Zero grazing ( $1=$ Yes, 0 = Otherwise $)$ & 0.48 & 0.50 \\
\hline $\begin{array}{l}\text { Pasturing in own village } \\
(1=\text { Yes, } 0=\text { Otherwise })\end{array}$ & 0.67 & 0.47 \\
\hline $\begin{array}{l}\text { Use of selected breeds } \\
(1=\text { Yes, } 0=\text { Otherwise })\end{array}$ & 0.21 & 0.41 \\
\hline Migration (1 = Yes, 0 = Otherwise) & 0.42 & 0.90 \\
\hline Restocking (number) & 0.41 & 0.49 \\
\hline Destocking (number) & 0.39 & 0.48 \\
\hline Hay production (kg) & 169.1 & 531.2 \\
\hline Straw production (kg) & 876.8 & 1,384 \\
\hline Purchase of hay (kg) & 80.5 & 379.9 \\
\hline Purchase of straw (kg) & 261.9 & 1,043 \\
\hline
\end{tabular}

Source: Collected by authors. Note: Tropical livestock unit (TLU) is meant to represent a live weight of tropical livestock given by $250 \mathrm{~kg}$ as a benchmark used for estimating other herds equivalently. On average, $1 \mathrm{TLU}=1 \mathrm{camel}=$ 0.7 cattle $=0.1$ sheep or goat $=0.5$ donkey $=0.45$ heifer or bull $=0.7$ mule or horse $=0.2$ bee colonies or $=0.01$ chickens (Randela et al. 2000)

reached primary level, and nobody went to secondary school. It was presumed that more educated people would have more awareness about the effects of climate change and ability to apply adaptation measures. The mean level of household's working experience in livestock farming was almost 25 years. The major livestock 
holdings across the household heads were cattle (oxen and cows), goats, sheep and camels (see Table 1).

Among livestock owners who already moved to other potential areas, $6 \%$ reported that they continued moving for more than one month until they get sufficient pasture and water sources. Once livestock owners moved to a certain district, they no longer keep moving if they find sufficient feed for their cattle. In the study, a majority of livestock owners (94\%) did not make repeating movements after they found adequate feed resources in certain areas. Hence, accessibility to animal feed and water resources determines household's movement.

\section{Perception of households on effects of climate change}

Households were requested to provide their views about whether they were sensitive to the effects of climate change. The majority reported that successive occurrences of droughts and the vulnerable nature of livestock farming in the Afar region had heightened their sensitivity in terms of crop failure and animal decimation over the last five years. Table 2 presents information about the perception of household heads across the four community groups and the degree of climatic effects they perceived. About $88.7 \%$ of the pastoralists significantly felt the effects of climate change in the form of recurring droughts, whereas the other $7.5 \%$ expressed their moderate feelings towards the effects. The remaining $3.8 \%$ of pastorals said they were unaware of the effects or did not know at all. Similarly, semi-pastoral (85.9\%), agro-pastoral (87.5\%) and mixed-farming (88.4\%) communities significantly perceived that prolonged drought was a major challenge that mainly damaged their natural resource base and was followed by lack of feed and water for people and animals (Table 2). Similarly, Masih et al. (2014) showed that drought severely harms the ecosystem and worsens human crises.

More than $94 \%$ of pastoral, semi-pastoral, agropastoral and mixed-farming communities perceived that a lack of animal feed was their critical challenge during drought periods. Crop failure that directly causes scarcity of animal feed is also associated with lack of rain and drying of water sources (Tsegaye et al. 2013). As a result, semi-pastoral (86.5\%), agro-pastoral (95.1\%) and mixed-farming (83.3\%) communities perceived that climate change, manifesting as drought, had significant destroyed crops. Households described that they experienced crop failure twice or more times within five years (Table 2). These show that the Afar people are vulnerable to the vagaries of nature. Because existing streams and rivers are drying up, pastoral (92.9\%), semi-pastoral (86.5\%), agro-pastoral (89.5\%) and mixed-farming (85.3\%) communities significantly perceived scarcity of water across many villages in Aba'ala. These community members further perceived the effects of climate change in terms of rainfall variability, increased temperature, untimely raining and flooding, prevalence of animal and human diseases, shortage of food for human and drying of streams and other water sources (See Table 2).

During drought, many livestock owners used the same water sources (rivers, ponds, wells and streams) for their animals to drink from. As expressed by key informants, cattle herds that compete for similar water sources and grazing land areas were likely to be exposed to several diseases. This shows the need for introducing better cattle management mechanisms such as zero grazing, provision of clean water and improved veterinary

Table 2 Perception of household heads on effects of climatic change

\begin{tabular}{|c|c|c|c|c|c|c|c|c|}
\hline \multirow[t]{3}{*}{ Effects of climate change } & \multicolumn{8}{|c|}{ Household's perception by community group (\%) } \\
\hline & \multicolumn{2}{|l|}{ Pastorals } & \multicolumn{2}{|c|}{ Semi-pastorals } & \multicolumn{2}{|c|}{ Agro-pastorals } & \multicolumn{2}{|c|}{ Mixed-farming } \\
\hline & Moderate & High & Moderate & High & Moderate & High & Moderate & High \\
\hline Recurrent drought & 7.5 & 88.7 & 7.0 & 85.9 & 8.2 & 87.5 & 6.5 & 88.4 \\
\hline Lack of animal fodder & 3.6 & 95.6 & 3.5 & 95.5 & 4.3 & 94.0 & 4.1 & 95.0 \\
\hline Crop failure & 0 & 0 & 12.5 & 86.5 & 10.5 & 85.1 & 11.8 & 83.3 \\
\hline Rainfall variability & 8.0 & 85.8 & 4.0 & 88.5 & 10.5 & 87.2 & 6.1 & 89.4 \\
\hline Drying of existing streams and rivers & 9.4 & 83.4 & 12.0 & 86.0 & 10.3 & 83.8 & 11.0 & 81.3 \\
\hline Scarcity of water & 4.8 & 92.9 & 12.5 & 86.5 & 6.8 & 89.5 & 8.2 & 85.3 \\
\hline Temperature change & 8.6 & 87.4 & 7.0 & 89.0 & 7.4 & 91.2 & 2.4 & 91.7 \\
\hline Prevalence of human diseases & 5.4 & 91.0 & 5.5 & 92.5 & 9.9 & 87.2 & 3.1 & 93.1 \\
\hline Prevalence of animal diseases & 4.4 & 89.5 & 6.8 & 92.0 & 7.4 & 88.1 & 3.7 & 91.2 \\
\hline Untimely raining and flooding & 8.4 & 85.3 & 13.5 & 89.5 & 7.9 & 87.7 & 3.0 & 93.0 \\
\hline Lack of human food & 9.6 & 83.0 & 12.5 & 86.0 & 6.0 & 88.0 & 4.9 & 87.1 \\
\hline
\end{tabular}

Source: Collected by authors 
services, which may address problems related to disease prevalence when livestock herds compete for scarce sources (mainly for water and grazing areas).

\section{Adaptation strategies pursued by communities in Aba'ala district}

This study attempted to explore correlations between households' perception of the changing climate and their adaptation actions applied in the last five consecutive years. For the analysis, household's perception runs from $0=\mathrm{I}$ don't feel, 1 = I don't know and 2 = I significantly felt. Table 3 presents percentage of households who perceived the adverse influences of climate change and their corresponding adaptation strategies. About $99.8 \%$ of pastoral communities perceived the ill effects of climate change. To cope with the effects, households pursue livestock mobility as their prime strategy. In the case of pastoral communities, we found that livestock farming was dominantly supporting their livelihood bases. Pastoral communities supplemented their living through livestock mobility to other potential areas where they could find water and natural grazing. On the contrary, about $94.1 \%$ of mixed-farming communities, $88.3 \%$ of agro-pastorals and $67.5 \%$ of semi-pastorals perceived livestock mobility as inferior strategy to other adaptation options. A statistical test shows households' significant differences in pursuing livestock mobility associated with their perception differences.

As shown in Table 3, perception of mixed-farming communities for practising zero grazing recorded the highest level (90.2\%). However, a small proportion of pastorals (27\%), semi-pastorals (32.5\%) and agro-pastorals (38\%) perceived zero grazing as an appropriate adaptation strategy. The study also showed that perception of households towards the use of pasturing and breeding was statistically insignificant differences among pastoral, semipastoral, agro-pastoral and mixed-farming communities. While $91 \%$ of mixed-farming strongly perceived livestock restocking as their means to respond to climate-related risks, pastorals (15.8\%), semi-pastorals (23\%) and agropastorals (19\%) showed only a negligible interest in this strategy. As reported by key respondents, most households perceived the importance of restocking, especially to improve their herds by purchasing drought resistant cattle and small ruminants. Perception of pastoral, semi-pastoral, agro-pastoral and mixed-farming communities towards the importance of livestock destocking accounted for 42.5, 36, 33 and $41 \%$, respectively (Table 3). Cropping was also extensively perceived as a pathway to cope with a multitude threats of climate change, upon which semi-pastoral (95.5\%), agro-pastoral (96.6\%) and mixed-farming (99.8\%) communities were highly dependent on to supplement their subsistence living.

Considering the strategy to reverse unexpected future climate shocks and uncertainties, agro-pastoral (44.9\%) and mixed-farming (51.3\%) communities used animal feed storage. This might be because livestock feed storage applied by the mixed-farming communities is associated with their long-term experience in cropping. Their involvement in cropping during good seasons (non-erratic rain season) allows them to harvest a sufficient amount of straw and hay, which would also enable them to keep stocking for unprecedented future feed crises. Key informants and group discussions further confirmed that feed stocking is possible, either through their own production, purchasing or both.

Irrigation was also perceived as a strategy to adapt to climate change by pastoral (12.9\%), semi-pastoral (79\%), agropastoral (81.8\%) and mixed-farming (94.7\%) communities.

Table 3 Association of household's perception with various adaptation strategies

\begin{tabular}{|c|c|c|c|c|c|c|}
\hline \multirow{2}{*}{$\begin{array}{l}\text { Adaptation methods to } \\
\text { climate change }\end{array}$} & \multicolumn{6}{|c|}{ Perception of households by community groups (\%) } \\
\hline & Pastorals & Semi-pastorals & Agro-pastorals & Mixed-farming & $\mathrm{Chi}^{2}$ & $P$ value \\
\hline Livestock mobility & 99.8 & 32.5 & 11.7 & 5.9 & 110.0 & $0.000^{* * *}$ \\
\hline Zero grazing & 27.0 & 32.5 & 38.1 & 90.2 & 472.4 & $0.000^{* * *}$ \\
\hline Pasturing in own village & 66.2 & 69.0 & 71.0 & 63.9 & 5.3 & 0.154 \\
\hline Use of selected breeds & 23.5 & 21.5 & 17.6 & 22.5 & 4.6 & 0.199 \\
\hline Livestock diversification & 45.5 & 16.5 & 24.1 & 23.3 & 143.4 & $0.000^{* * *}$ \\
\hline Off-farm & 88.3 & 80.0 & 88.5 & 85.5 & 8.3 & $0.040^{* *}$ \\
\hline Restocking & 15.8 & 23.0 & 19.0 & 91.0 & 740.0 & $0.000^{* * *}$ \\
\hline Destocking & 42.5 & 36 & 33.0 & 41.0 & 9.6 & $0.000^{* * *}$ \\
\hline Cropping & 0 & 95.5 & 96.6 & 99.8 & 150.0 & $0.000^{* * *}$ \\
\hline Spate irrigation & 12.9 & 79.00 & 81.8 & 94.7 & 47.6 & $0.000^{* * *}$ \\
\hline Feed storage & 0 & 3.8 & 44.9 & 51.3 & 48.0 & $0.000^{* * *}$ \\
\hline
\end{tabular}

Note: *** and ${ }^{* *}$ denote significance at 1 and $5 \%$ levels, respectively. Source: Collected by authors 
Despite water scarcity being a major challenge in the Aba'ala district, mixed-farming communities used to grow cereal crops with spate irrigation. As reported by key informants, this practice started in the 1960s when cropping started in Aba'ala. Experienced farmers who were involved in spate irrigation described that the use of flood diversion into farmlands provided several benefits. For example, farmers were able to grow cereal crops, enrich water wells and ponds for humans and animals, alleviate moisture stress and keep ecological balance. With respect to pastorals and semi-pastorals, livestock mobility to other areas in search of water and natural grazing is crucial for sustenance (Tsegaye et al. 2013).

\section{Income sources}

In addition to the aforementioned adaptation strategies, communities in the Afar region attempted to be involved in various income-generating activities. Income from livestock is among multiple sources that support the livelihoods of rural communities. As presented in Table 4, this sector serves as the main source of living for 105 pastoral, 40 semi-pastoral, 70 agro-pastoral and 98 mixed-farming communities. The contribution of livestock accounted for about $65.7 \%$ of the total income. In order to estimate the net income generated from livestock, all expenses made for purchasing fodder, payments for hired labour and fees for veterinary services were deducted from total gross income. All components of livestock income sources such as sales of live animals, milk, butter oil, hides and skins were accounted for.

In the Ab'ala district, community members generated income from non-agricultural wages. For instance, 54 pastoral, 39 semi-pastoral, 54 agro-pastoral and 80 mixed-farming communities took employment from several organizations. Self-employment was also found as the key income strategy to the rural communities. There were 15 pastoral, 6 semi-pastoral, 7 agro-pastoral and 23 mixed-farming communities who engaged in generating several income-generating enterprises. Households who engaged in crop production accounted for nearly 191 people across the district. Among these, 39 were semipastoral, 54 agro-pastoral and 98 mixed-farming communities. About 14\% of the income of those household heads was supplemented from cropping. As shown in Table 4, both relief and remittance also contributed to households' total income share by 14.1 and $0.23 \%$, respectively.

A total of 92 pastoral, 33 semi-pastoral, 59 agropastoral and 69 mixed-farming communities generate income from selling firewood and charcoal, accounting for about $4.1 \%$ of the total income and implying reliance on exploiting the natural forests for energy and commercial purposes (Table 4). This may be taken as an indication of how income constraints can pressure rural people to keep on selling firewood and charcoal to meet their short-term needs without considering the longterm burdens on the natural resource base. Hence, continual damage of the natural forest can accentuate the negative effects of climatic change in the area. In this context, the key informants further recommended urgent measures to enable the fuel-wood sellers to shift to compatible income diversification alternatives like honey, salt mining, commercial tree plantation, livestock rearing and trading, which are eco-friendly livelihood alternatives. Similar conclusions made by Habibah et al. (2010) indicate that locals can be active participants in protecting the natural resources if they find that they could maintain their long-term benefits in sustainable ways.

\section{Adaptation via cattle management}

Natural pasture has continued to be the dominant source of feed for livestock. Beginning in the 1960s, however, an influx of migrating people from highland areas along with the indigenous Afar began settling in specific villages (Tsegaye et al. 2013). Consequently, cropping was introduced in Aba'ala. Owing to repeated droughts over series of years, rural farmers realized that

Table 4 Income share and number of households involved in various income sources

\begin{tabular}{|c|c|c|c|c|c|}
\hline \multirow{2}{*}{$\begin{array}{l}\text { Various income options pursued } \\
\text { by households }(n=313)\end{array}$} & \multirow{2}{*}{$\begin{array}{l}\text { Income } \\
\text { share } \\
(\%)\end{array}$} & \multicolumn{4}{|c|}{ Number of households across community groups } \\
\hline & & Pastorals & Semi-pastorals & Agro-pastorals & Mixed-farming \\
\hline Income from livestock & 65.7 & 105 & 40 & 70 & 98 \\
\hline Income from non-agricultural wage & 0.62 & 54 & 39 & 54 & 80 \\
\hline Income from cropping & 14.1 & 0 & 39 & 54 & 98 \\
\hline Income from remittance & 0.23 & 11 & 5 & 9 & 11 \\
\hline Income from relief & 14.1 & 103 & 39 & 71 & 98 \\
\hline Income from sales of fuel wood & 4.1 & 92 & 33 & 59 & 69 \\
\hline Income from agricultural wage & 1.03 & 0 & 0 & 14 & 98 \\
\hline Income from self-employment & 0.08 & 15 & 6 & 7 & 23 \\
\hline
\end{tabular}

Source: Collected by authors 
storing animal feed such as straws and hay would be of paramount importance to save the lives of their livestock. As shown in Table 5, farmers in the Aba'ala district harvested hay and straw across the five years (2011 to 2015). The low harvest of hay and straw during 2015 may be because of the severe drought that Ethiopia experienced that year. In this period, crop growers, agropastoral and semi-pastoral communities in the Aba'ala district did not produce any crop. Despite the severe drought in 2015, livestock owners purchased much less hay and straw than they purchased in the preceding years. This might be because the purchase of animal feed for the entire year is costly and unaffordable to locals; rather, households opted to move their livestock to eastern Afar in search of feed. According to the informants, most of the communities in the study area (mixed-farming, agro-pastoral and semi-pastoral) are involved in forage production. During normal rainy seasons, agro-pastoral and mixed-farming communities dominantly collect livestock feed.

\section{Effects of adaptation actions on income of households} In the face of the changing climate and realizing the consequent adverse effects, rural communities in Afar continue applying a number of adaptation methods provided that they expect benefits out of their adaptation actions (Di Falco et al. 2011, 2012; Kato et al. 2011). In this section, we examine the linkages between various types of adaptation measures and their corresponding effects on the income of pastoral, semi-pastoral, agropastoral and mixed-farming communities in the Afar region. Prior to estimations, we conducted several tests to verify which model was appropriately needed for doing the analysis. As individual sampled households were proportionally drawn from the four types of communities, estimation of adaptation effects on income of households necessitates considering two key potential sources of variation, which means at both individual and group levels. While estimation using ordinary least square (OLS) is useful to capture individual variations, random effects model incorporates non-systematic variances across groups and entities. Thus, mixed OLS-

Table 5 Adaptation to climatic change via cattle feeding

\begin{tabular}{lllllll}
\hline Year & \multicolumn{2}{l}{ Amount produced in $\mathrm{kg}$} & & \multicolumn{3}{c}{ Amount purchased in $\mathrm{kg}$} \\
\cline { 2 - 3 } \cline { 6 - 7 } & Hay & Straw & & Hay & Straw & Formula feed \\
\hline 2011 & 214.7 & 1020.6 & & 0 & 42.1 & 13.5 \\
2012 & 166.4 & 986.8 & & 0 & 12.8 & 7.8 \\
2013 & 211.3 & 787.6 & & 76.7 & 398.6 & 197.3 \\
2014 & 242.9 & 826.6 & & 196.8 & 681.0 & 374.9 \\
2015 & 10.1 & 762.3 & & 103.6 & 174.9 & 157.5 \\
\hline
\end{tabular}

Source: Collected by authors random effects test allows distinguishing what proportion of the variance in income can be attributed by individual differences compared to group differences arising from the four communities (see Appendix 1).

The estimated result of the Intraclass Correlation Coefficient (ICC) shows that nearly $35 \%$ of the variance among household income is due to adaptation differences attributed to the four community groups, whereas the remaining $65 \%$ is due to adaptation differences across individual households. As estimated results using ordinary least square (OLS) regression only account for individual variations and ignore average variances across community groups, the use of OLS provides biased coefficients. Moreover, the null hypothesis of no differences among the parameters of the four community groups is rejected using the likelihood ratio test. Evidence of the likelihood ratio (LR) test versus linear regression yields Prob $=0.0000$, which clearly shows the need to deploy other estimation methods. Considering these results, we further checked whether random effects or fixed effects model can appropriately capture both individual and group variations.

Following Wooldridge (2002) and Baltagi (2005), the statistical justification for the use of the fixed effects model over the random effects model was checked using the Hausman test. The test revealed that the null hypothesis that assumed random differences in coefficients is found statistically and significantly different from zero at $1 \%$ level $($ Prob $>$ chi $=0.0000)$. This justifies the rejection of the null hypothesis and the need to employ consistent estimation using the fixed effects model. Beyond this, we checked whether serial correlation had spiral effects on the dependent variable (income) by applying dynamic fixed effects regression over four consecutive lagged years (Appendix 2). The output showed that variations observed in the dependent variable were not statistically associated with unprecedented effects that might arise from previous years.

The correlation coefficient $\left(\rho_{i}\right)$ between residuals within groups and the overall error term shows the effect of time differences across the panel years. As shown in Table 6, the attribution of such differences over the course of the five years (2011 to 2015) was found to hold nearly $53.6 \%$ of the total variation in the dependent variable (income). This further explains the presence of heterogeneity across individuals along with time effects. The use of fixed effects model in this situation, therefore, distinctively differentiates the effects of adaptation measures applied by individual households from the effects attributed to panel years. As shown in Table 6, the results of the fixed effects regression show that the major adaptation actions that are found to have statistically significant effects on the income of households are water harvesting, livestock diversification, migration and production of hay and straw. 
Table 6 Effects of adaptation actions on annual income using fixed effects model

\begin{tabular}{|c|c|c|}
\hline Variables & Coefficient & Standard error \\
\hline Age of household head & -90.1 & $30.1^{\mathrm{a}}$ \\
\hline $\begin{array}{l}\text { Family members whose age } \\
\text { below } 15 \text { years (number) }\end{array}$ & 162.0 & 103.1 \\
\hline $\begin{array}{l}\text { Family members whose age } \\
15 \text { to } 64 \text { years (number) }\end{array}$ & 39.4 & 67.9 \\
\hline $\begin{array}{l}\text { Family members whose age } \\
\text { above } 64 \text { years (number) }\end{array}$ & -185.4 & 471.1 \\
\hline Number of cattle & -3.1 & 29.4 \\
\hline Number of goats & -3.2 & 4.6 \\
\hline Number of sheep & -71.2 & 168.7 \\
\hline Number of camel & 53.0 & 70.2 \\
\hline Stocking fodder & 77.6 & 212.7 \\
\hline Access to extension services & 286.4 & 179.7 \\
\hline Access to water sources & 949.7 & $448.5^{b}$ \\
\hline Cropping & 407.1 & 443.7 \\
\hline Livestock mobility & 551.9 & $209.5^{\mathrm{b}}$ \\
\hline Zero grazing & 32.9 & 148.9 \\
\hline Pasturing in own village & -50.8 & 107.6 \\
\hline Use of selected breeds & 104.6 & 119.4 \\
\hline Livestock diversification & 913.7 & $447.6^{\mathrm{b}}$ \\
\hline Off-farm & 262.6 & 144.3 \\
\hline Restocking & 195.9 & 143.3 \\
\hline Destocking & -11.8 & 99.1 \\
\hline Purchase of straw & 0.06 & 0.04 \\
\hline Purchase of hay & -0.03 & 0.11 \\
\hline Purchase of formula feed & -0.03 & 0.13 \\
\hline Hay production & 93.6 & $20.6^{\mathrm{a}}$ \\
\hline Straw production & 35.05 & $15.1^{b}$ \\
\hline Income lag year & 2.8 & 32.5 \\
\hline Constant & 856.9 & $65,921.6$ \\
\hline $\begin{array}{l}\text { Rho }\left(\rho_{i}\right)=0.536 \\
F(312,1220)=2.55 \text { Prob }>F=0.0000\end{array}$ & & \\
\hline
\end{tabular}

Note: and ${ }^{\mathrm{b}}$ denote significance at $1 \%$ and $5 \%$ levels, respectively. Source: Collected by authors

The estimated coefficient on age of household heads may help associate both labour force age group and various adaptation measures applied at village level. As illustrated in Table 6, age of household head was negatively and significantly related to the annual mean income. The negative result of the household head's age may indicate that older people who could not fit physically to accomplish adaptation activities cannot improve their income level. As uptake of improved adaptation practices is difficult for older households, they remain to stick on applying traditional practices that already known to them (Abdulai and CroleRees 2001). This might be because older people usually tend to devote their time and resources on religious affairs. In the Afar culture, it is believed that old age is the time for doing charity and sanity. Considering the social and economic dynamic, key informants reported that older people usually do not commit in meeting long-term planning towards improving their income benefits. In most cases, older people in rural villages persistently rely on practising their own old experiences, which might not fit the varying nature of climatic changes. Realizing that they could not actively manage to boost their income sources, they rather transfer their wealth to their children in the form of gift or bequest. Even if they have long-term prospects to re-invest their financial holdings, older people commonly rely on supports from young family members (Tsegaye et al. 2013).

In the Afar drylands areas where households are sensitized to the effects of drought occurrences, access to water harvesting actions could have important implications on their income improvement. In this study, access to water sources was found to have a positive and statistically significant effect on household income (Table 6). The positive result suggests that most agro-pastoralists and mixed-farming communities sought to cope with several drought events by engaging in various small scale irrigation schemes such as flood diversion from the Tigray highlands, which had positively contributed to their income. Most mixed-farming communities and agropastoralists that relied on perennial water sources produce vegetables and crops whereas semipastoralists and pastoralists that live distantly from perennial water sources depend on ponds that might be used only for few months. Moreover, community members who are near to perennial water sources are able to enhance sedentary way of life due to the opportunity it offers them for better access to animal feed and improved income. In tackling droughtrelated challenges owing to climate change, farm communities who are aware of the importance of water sources for the improvement of their income sources have engaged in water harvesting activities.

Households widely used livestock mobility to adapt to the effects of climate change. Particularly, the Afar pastorals, semi-pastorals and agro-pastorals moved to potential areas where they could find natural grazing and water sources for their livestock. As shown in Table 6, the estimation results of the fixed effects model indicate that migration is positively and significantly related to the household income. The results further reveal that households who keep moving their cattle herds to better pasture had achieved higher income than those who never moved. In congruence with this finding, Moritz et al. (2009) indicated that livestock mobility is the innovative means of sustaining rural livelihoods by which 
pastoralists are able to fully utilize untapped rangeland resources in distant areas. Household heads further explained their past experiences that livestock mobility has been used to escape away during a disease breakout in a specific area.

In the Afar culture, people widely share information and new events by way of traditional communication called Dagu (face to face contact). With the help of getting information via Dagu, pastorals and agro-pastorals used to move their livestock to safer areas. Overall, migration for the Afar pastoralists serves as a means to search livestock feed and water, as a strategy to rescue their livestock from unexpected events, as a channel to reach new market opportunities and as a pathway to build social capital with newly contacted people in their destination areas (McPeak et al. 2012). More importantly, pastoral mobility serves a source of income in areas where crop cultivation has not yet been applied. Recently, reported research findings indicated that pastoralists in west and east African countries have continued to respond to climate-related challenges by moving their livestock to better areas (Moritz et al. 2009). In contrary, other research reports suggest that the pastoral mode of life is an outdated system, which is currently in crisis (Markakis 2004) owing to 'too many people and few livestock', which has created imbalances among humans, livestock and the environment (Sandford 2006).

Besides cattle, livestock diversification that includes small ruminants is found to have a significant relationship with income (Table 6). The pursuance of households on diversified livestock strategies might allow them to build locally fitting adaptive capacity, which would enable them to address problems related to climatic risks and uncertainties. In the study area, households that diversify their livestock had easy access to liquid money via sales of livestock products and live animals. Likewise, Degefa (2005) reported that people that pursue diversified income sources through production of improved livestock varieties such as cattle, camel, goats and sheep are more likely to achieve sustainable livelihoods. The implication is that diversified income may serve as a means to heighten the purchasing power of pastoralists and agro-pastoralists, by which they can easily access staple foods and veterinary services (animal health and artificial insemination).

It was also found that getting access to animal feed through production of hay and straw had a positive and statistically significant effect on income (Table 6). The positive effect of animal feed on the mean income shows that households would like to gather hay and straw to reduce unexpected losses of animals due to risks associated to lack of fodder. On one side, households that collected animal feed using own family labour were able to save some portion of money that might have spent for hiring labour. This suggests that households having easy access to collect hay and straw are more likely to earn a higher income. Therefore, communities in the Afar region put their efforts into collecting hay and straw to feed their animals. Particularly, feed collection in Aba'ala is usually practised by mixed-farming and agro-pastoral community members during THE wet season. Informants further expressed that livestock owners who collected excess hay and straw can earn extra income by selling some of it during dry season.

\section{Conclusion and recommendation}

This study provides an analysis to verify whether rural people perceive adverse effects of climate change and the mitigation strategies that might be used to diversify income or mitigate costs by pastoral, semi-pastoral, agro-pastoral and mixed-farming communities in the drylands of the Afar region, northern Ethiopia. Household heads perceived that climate change considerably disrupted raining seasons and caused repeating occurrences of droughts, temperature change, prevalence of diseases, drying of water sources and lack of human and livestock feed. Households mainly observed the direct consequences of climate change in the form of loss of livestock and crop failure, which eventually threatened their short-term and long-term welfare. The study found that the communities in the Aba'ala district were highly sensitized to the adverse effects of climate change and coped by adaptation measures suitable to their local environments, including diversifying income sources, gathering animal feed, cropping, feed purchase, livestock diversification, livestock mobility, applying various irrigation schemes and use of selected livestock breeds.

Results from our fixed effects regression model showed that access to water sources, livestock mobility, production of hay and straw and livestock diversification were the major determinants that significantly influenced the income of households. Mainly, the study found that pastoralists and semi-pastorals in the Afar region widely practised livestock mobility as their most important strategy to cope with drought effects. However, the income of households from sales of firewood and charcoal needs to be replaced by providing them with accessible and sustainable options like honey production, salt mining, commercial tree plantation, livestock rearing and trading. Extensive intervention on promulgating water harvesting schemes would largely help communities in the Afar region. This would enable households to produce animal feed (hay and straw) and create a better chance to use diversified livestock rearing. Depending on the types of livelihood sources, innovative advisory services are highly required to each community member. Mainly, the existing pastorals ways of livestock mobility have to be improved by educating livestock herders via provision of improved veterinary services, livestock management and continuous training. 


\section{Appendix}

Table 7 Mixed OLS-random effects test

\begin{tabular}{|c|c|c|c|c|}
\hline Mixed effects REML regression & \multicolumn{4}{|c|}{ Number of obs $=1559$} \\
\hline \multirow[t]{6}{*}{ Group variable: household type } & \multicolumn{4}{|c|}{ Number of groups $=4$} \\
\hline & \multicolumn{4}{|c|}{ Obs per group: $\min =200$} \\
\hline & \multicolumn{4}{|c|}{ Avg $=389.8$} \\
\hline & \multicolumn{4}{|l|}{$\operatorname{Max}=521$} \\
\hline & \multicolumn{4}{|c|}{ Wald $\operatorname{chi}^{2}(26)=112.90$} \\
\hline & \multicolumn{4}{|c|}{ Prob $>c h i^{2}=0.0000$} \\
\hline \multicolumn{5}{|c|}{ Log restricted-likelihood $=-13,654.499$} \\
\hline Random effects parameter & Estimate & Standard error & {$[95 \%$ con } & \\
\hline Household type: (Sigma_u) & 1213.958 & 503.6702 & 538.3207 & 2737.578 \\
\hline Individual: (Sigma_e) & 1663.82 & 30.08656 & 1605.884 & 1723.846 \\
\hline \multicolumn{5}{|c|}{ LR test vs. linear regression: $\operatorname{chibar}^{2}(01)=171.84 \operatorname{Prob}=\operatorname{chibar}^{2}=0.0000$} \\
\hline
\end{tabular}

$$
\text { Intraclass Correlation Coefficient }(\text { ICC })=\frac{(\text { Sigma_u })^{2}}{(\text { Sigma_e })^{2}+(\text { Sigma_u })^{2}}=\frac{(1213.958)^{2}}{(1213.958)^{2}+(1663.82)^{2}}=0.35
$$

Table 8 Regression outputs of dynamic fixed effects model against the dependent variable

\begin{tabular}{|c|c|c|c|c|c|c|c|c|}
\hline \multirow[t]{2}{*}{ Variables } & \multicolumn{2}{|c|}{ Lag year 1} & \multicolumn{2}{|c|}{ Lag year 2} & \multicolumn{2}{|c|}{ Lag year 3} & \multicolumn{2}{|c|}{ Lag year 4} \\
\hline & Coef. & Std. Err. & Coef. & Std. Err. & Coef. & Std. Err. & Coef. & Std. Err. \\
\hline Age of household head & -418.3 & 113.7 & -162.9 & 73.3 & -378.9 & 448.8 & -307.2 & 466.5 \\
\hline Family members whose age below 15 years & 127.2 & 160.1 & 456.3 & 248.3 & -149.2 & 61.5 & -150.2 & 60.8 \\
\hline Family members aged between 15 and 64 years & -20.7 & 130.5 & 315.2 & 168.3 & 363.9 & 208.9 & 307.8 & 207.7 \\
\hline Family members whose age above 64 years & 584.8 & 748.2 & -176.2 & 803.8 & 248.2 & 140.7 & 203.2 & 139.7 \\
\hline Number of cattle & 58.1 & 45.7 & 85.3 & 55.9 & -113.9 & 728.9 & 44.9 & 773.4 \\
\hline Number of goats & -5.1 & 6.4 & 0.3 & 6.70 & 75.1 & 51.2 & 70.0 & 51.2 \\
\hline Number of sheep & 49.8 & 205.3 & -327.8 & 209.6 & 0.8 & 6.0 & 1.7 & 6.2 \\
\hline Number of camel & 91.2 & 68.8 & -18.9 & 135.9 & -274.9 & 177.5 & -297.8 & 209.2 \\
\hline Stocking fodder & 359.1 & 334.0 & 264.4 & 398.4 & -32.5 & 116.9 & -33.5 & 114.1 \\
\hline Access to extension services & 89.5 & 402.8 & 438.7 & 455.9 & 149.3 & 369.8 & 219.1 & 378.7 \\
\hline Access to water sources & 390.1 & 293.5 & 149.9 & 407.8 & 385.1 & 387.7 & 381.3 & 425.7 \\
\hline Cropping & 408.6 & 367.6 & 260.7 & 739.1 & 126.3 & 383.4 & 24.6 & 354.9 \\
\hline Livestock mobility & 506.7 & 441.8 & 664.7 & 522.6 & 224.0 & 703.5 & 296.3 & 652.5 \\
\hline Zero grazing & 117.5 & 225.6 & -314.5 & 280.9 & 621.8 & 500.0 & 676.4 & 503.6 \\
\hline Pasturing in own village & -148.4 & 155.3 & 32.8 & 180.9 & -322.1 & 268.9 & -397.4 & 252.4 \\
\hline Use of selected breeds & 28.5 & 173.2 & 44.4 & 224.6 & 87.2 & 198.0 & 81.7 & 200.1 \\
\hline Livestock diversification & 983.3 & $1,116.5$ & $1,186.2$ & $1,275.1$ & 87.2 & 198.0 & $1,351.4$ & $1,238.5$ \\
\hline Off-farm & 94.2 & 184.4 & 225.5 & 234.4 & $1,320.5$ & $1,340.9$ & 233.9 & 220.4 \\
\hline Restocking & 94.3 & 210.8 & 410.4 & 233.5 & 225.5 & 223.6 & 344.4 & 210.1 \\
\hline Destocking & 51.1 & 140.2 & 4.5 & 148.2 & 389.1 & 209.5 & 51.4 & 143.7 \\
\hline Purchase of straw & 0.1 & 0.1 & 0.1 & 0.10 & -9.8 & 135.6 & 0.04 & 0.04 \\
\hline Purchase of hay & 0.1 & 0.1 & -0.1 & 0.20 & 0.04 & 0.10 & -0.07 & 0.16 \\
\hline
\end{tabular}


Table 8 Regression outputs of dynamic fixed effects model against the dependent variable (Continued)

\begin{tabular}{lllllllll}
\hline Purchase of formula feed & 0.1 & 0.2 & -0.1 & 0.10 & -0.1 & 0.20 & -0.08 & 0.13 \\
Hay production & 75.8 & 44.9 & 134.1 & 77.9 & -0.1 & 0.10 & 129.6 & 71.7 \\
Straw production & 6.1 & 28.1 & 8.3 & 29.7 & 148.3 & 75.0 & 0.5 & 26.7 \\
Income lag year & & & 0.1 & 0.07 & 3.9 & 27.5 & -0.06 & 0.05 \\
Constant & $25,578.15$ & $6,128.6$ & $5,323.5$ & $4,087.5$ & -0.1 & 0.10 & $6,868.1$ & $3,776.1$ \\
\hline
\end{tabular}

Source: Collected by authors

\section{Acknowledgements}

The authors would like to thank Mekelle University, Colorado State University and Japan International Research Center for Agricultural Sciences (JIRCAS) for supporting this study.

\section{Authors' contributions}

All the authors have developed the concept and design of the study. While data collection was done by $\mathrm{MB}$, supervision during survey implementation was done by DH, GT, T, SO, MK and CK. The manuscript was proof read, revised and approved by all authors for final submission. All authors read and approved the final manuscript.

\section{Competing interests}

The authors declare that they have no competing interests.

\section{Publisher's Note}

Springer Nature remains neutral with regard to jurisdictional claims in published maps and institutional affiliations.

\section{Author details}

'Department of Agricultural and Resource Economics, College of Dryland Agriculture and Natural Resources, Mekelle University, P.O.Box 231, Mekelle, Ethiopia. ${ }^{2}$ Department of Agricultural and Resource Economics, Colorado State University, Fort Collins, CO 80523-1172, USA. ${ }^{3}$ Social Sciences Division, Japan International Research Center for Agricultural Sciences (JIRCAS), Tsukuba, Japan. ${ }^{4}$ Faculty of Agriculture, Kyoto University, Kyoto, Japan. ${ }^{5}$ Environmental Studies (Economics), School of Science and the Environment, Memorial University, Grenfell Campus, 20 University Drive, Corner Brook, NL A2H 5G4, Canada

Received: 28 October 2016 Accepted: 23 February 2017

Published online: 30 May 2017

\section{References}

Abdulai, A., and A. CroleRees. 2001. Determinants of income diversification amongst rural households in Southern Mali. Food Policy 26: 437-452.

Adger, W.N., N.W. Arnell, and El Tompkins. 2005. Successful adaptation to climate change across scales. Global Environmental Change 15: 77-86.

African Technology Policy Studies Network. 2013. The rationale and capacity of pastoral community innovative adaptation to climate change in Ethiopia. ATPS Research Paper No. 25.

Baltagi, B.H. 2005. Econometric analysis of panel data, 3rd ed. West Sussex: John Wiley and Sons Ltd.

Barberies, N.C. 2013. Thirty years of prospect theory in economics: A review and assessment. Journal of Economic Perspectives 27: 173-196.

Berhanu, W., D. Colman, and B. Fayissa. 2007. Diversification and livelihood sustainability in a semi-arid environment: A case study from southern Ethiopia. Journal of Development Studies 43: 871-889.

Bradburd, D. 1982. Volatility of animal wealth among southwest Asian pastoralists. Human Ecology 10: 85-106

Campbell, D.J., D.P. Lusch, T.A. Smucker, and E.E. Wangu. 2005. Multiple methods in the study of driving forces of land use and land cover change: A case study of SE Kajiado District, Kenya. Human Ecology 33: 763-794.

Chala, K., O.E. Taye, D. Kebede, and T. Tadele. 2012. Opportunities and challenges of honey production in Gomma district of Jimma zone, south-west Ethiopia. Journal of Agricultural Extension and Rural Development 4: 85-91.
Crane, T.A., C. Roncoli, and G. Hoogenboom. 2011. Adaptation to climate change and climate variability: The importance of understanding agriculture as performance. NJAS-Wageningen Journal of Life Sciences 57: 179-185.

CSA (Central Statistical Authority). 2008. Report of the 2007 population and housing census. Addis Ababa: CSA.

Degefa, T. 2005. Rural livelihoods, poverty and food insecurity in Ethiopia: A case study at Erenssa and Garbi communities in Oromia zone. Amhara National Regional State, PhD Thesis, Norwegian University of science and Technology, UTNU Trondheim.

Di Falco, S., M. Veronesi, and M. Yesuf. 2011. Does adaptation to climate change provide food security? A micro-perspective from Ethiopia. American Journal of Agricultural Economics 93: 825-842.

Di Falco, S., M. Yesuf, G. Kohlin, and C. Ringler. 2012. Estimating the impact of climate change on agriculture in low-income countries: Household level evidence from the Nile Basin, Ethiopia. Environmental Resource Economics 52: 457-478.

FAO. 2012. Environment and natural resource management: Adaptation to climate change in semi-arid environments experience and lessons from Mozambique, 71. Rome: FAO.

Galvin, K.A. 2009. Transitions: Pastoralists living with change. Annual Review of Anthropology 38: 185-189.

Habibah, A., J. Hamzah, and I. Mushrifah. 2010. Sustainable livelihood of the community in Tasik Chini biosphere reserve: The local practices. Journal of Sustainable Development 3: 184-196

Hogg, R. 1992. Should pastoralism continue as a way of life? Disasters 16: 131-137.

International Labour Office (ILO). 2011. The dynamics of employment, the labour market and the economy in Nepal (Geneva). http://www.ilo.org/publns. Accessed 22 Jan 2016.

Kato, E., C. Ringler, M. Yesuf, and E. Bryan. 2011. Soil and water conservation technologies: A buffer against production risk in the face of climate change? Insights from the Nile Basin in Ethiopia. Agricultural Economics 42: 593-604

Kima, S.A., A.A. Okhimamhe, A. Kiema, N. Zampaligre, and I. Sule. 2015. Adapting to the impacts of climate change in the sub-humid zone of Burkina Faso, West Africa: Perceptions of agro-pastoralists. Pastoralism 5: 1-14.

Kiviet, J.F. 1995. On bias, inconsistency and efficiency of various estimators in dynamic panel data models. Journal of Econometrics 68: 53-78.

Kloos, H. 1982. Farm labor migrations in the Awash valley of Ethiopia. International Migration Review 16: 133-168.

Markakis, J. 2004. Pastoralism on the margin, report. London: Minority Rights Group International.

Masih, I., S. Maskey, F.E.F. Mussa, and P. Trambauer. 2014. A review of droughts on the African continent: A geospatial and long-term perspective. Hydrology and Earth System Science 18: 3635-3649.

McPeak, J., P. Little, and C. Doss. 2012. Risk and social change in an African rural economy: Livelihoods in pastoral communities. Oxford: Routledge.

Meze-Hausken, E. 2004. Contrasting climate variability and meteorological drought with perceived drought and climate change in northern Ethiopia. Climate Research 27: 19-31.

Moritz, M., B. Kyle, K.C. Nolan, S. Patrick, M.F. Shaffer, and G. Thampy. 2009. Too many people and too few livestock in West Africa? An evaluation of Sandford's thesis. Journal of Development Studies 45: 1113-1133.

Nassef, M., S. Anderson, and C. Hesse. 2009. Pastoralism and climate change: Enabling adaptive capacity. London: HPG Report, Overseas Development Institute.

Nickell, S. 1981. Biases in dynamic models with fixed effects. Econometrica 49: 1417-1426.

OXFAM. 2008. Survival of the fittest: Pastoralism and climate change in east Africa. UK: OXFAM. Oxfam Briefing Paper No. 116. 
Randela, R., G.F. Liebenberg, J.F. Kirsten, and R.F. Townsend. 2000. Demand for livestock tick control service in the Venda region, Northern Province. Agrekon 39: 644-655.

Sandford, S. 2006. Too many people, too few livestock: The crisis affecting pastoralists in the Greater Horn of Africa, a thesis. Future Agricultures. http://www.future-agricultures.org/publications/e-debate/pastoralism-incrisis/7646-too-many-people-too-few-livestock Accessed on 13 Mar 2016

Seo, S.N., and R. Mendelsohn. 2008. Animal husbandry in Africa: Climate change impacts and adaptations. African Journal of Agricultural and Resource Economics 2: 65-82.

Smit, B., I. Burton, R.J.T. Klein, and J. Wandel. 2000. An anatomy of adaptation to climate change and variability. Climatic Change 45: 223-251.

Stringer, L.C., S.S. Scrieciu, S. Mark, and M.S. Reed. 2009. Biodiversity, land degradation, and climate change: Participatory planning in Romania. Applied Geography 29: 77-90.

Tsegaye, D., S.R. Moe, P. Vedeld, and E. Aynekulu. 2010. Land-use covers dynamics in northern Afar rangelands, Ethiopia. Agriculture, Ecosystems and Environment 139: $174-180$

Tsegaye, D., P. Vedeld, and S.R. Moe. 2013. Pastoralists and livelihoods: A case study from northern Afar, Ethiopia. Journal of Arid Environments 91: 138-146.

Verbeek, M. 2004. A guide to modern econometrics, 2nd ed. Chichester: John Wiley and Sons Ltd.

Wassie, B., and B. Fekadu. 2014. The impact of climate change on pastoral production systems. A study of climate variability and household adaptation strategies in southern Ethiopian rangelands.. WIDER Working Paper 2014/028.

Wooldridge, J.M. 2002. Econometric analysis of cross section and panel data. London: The MIT Press.

\section{Submit your manuscript to a SpringerOpen ${ }^{\circ}$ journal and benefit from:}

- Convenient online submission

- Rigorous peer review

- Immediate publication on acceptance

- Open access: articles freely available online

- High visibility within the field

- Retaining the copyright to your article

Submit your next manuscript at $\gg$ springeropen.com 